\title{
The Arts as Portals for Understanding "The Other"
}

\author{
By Barbara Pemberton *
}

\begin{abstract}
Anthropological studies show the polarization of "sacred and profane" has emerged autonomously in all human societies. It follows that all religious traditions have identified special portals through which adherents may delve into what they have set apart as sacred. These portals include inspiring natural locations, sacred texts, architecture, and the fine arts. When encountered, these portals elicit powerful emotions - they speak to us and foster dialogue. This paper will encourage introducing students to the study of other religious traditions by way of sacred portals, and in particular, the use of the arts to empathetically understand and engage "the other." Even though what is held to be sacred to one person may be a source of trepidation to another we must take the time to instill the value of, and the respect due, all that is considered sacred, especially that which is held sacred by "the other."
\end{abstract}

\section{Introduction}

Humans are innately religious and artistic. We sense that there is something beyond this material existence and we express both the search for and the experience of this "otherness" creatively. This makes the arts, both visual and performing, natural vehicles for the introduction and study of world religions. To illustrate, in this essay I will offer examples from the arts of a few faith traditions, beginning with recognizable symbols of each. It is hoped that these entry points into other beliefs will inspire the reader to further investigate the arts in world religions, so that what once seemed foreign, or "other," will become familiar, appreciated, and even enjoyed. I grew up a serious student of piano and ballet, dancing with a company in my young adult years. Pursuing a doctorate in world religions later in life did not mean leaving the arts behind; the arts became a marvelous vehicle for understanding "the other."

\section{The Arts As Portals}

All societies establish a polarization of reality between the sacred and the profane. ${ }^{1}$ Each community must then identify portals through which it may

\footnotetext{
* Professor, Ouachita Baptist University, USA.

1. Mircea Eliade, and Willard R. Trask, The Sacred and the Profane: The Nature of Religion (New York: Harcourt, Brace \& World, 1959).
} 
access what it has set aside as sacred. Some devotees use these portals to look within themselves for enlightenment; some believers look to their community for ultimate meaning; other seekers look beyond the human realm to that which is held to be transcendent. Among these portals into the sacred we find inspiring natural locations, sacred texts, architecture, and the fine arts. These portals of field and waterfall, of canvas and stone, of choir loft and stage may be engaged privately, or communally, each conveying complex layers of meanings. While the arts transcend space and time, they also best represent the lived experience of most religious traditions. ${ }^{2}$ They elicit powerful emotions - from joy and thoughtful reflection to angst and provocation which can lead to both interfaith dialogue and interdisciplinary discussion on topics as diverse as environmental change and social justice.

As a professor of world religions trained as an empathetic phenomenologist, I recognize seven interconnected aspects of each "life way": the mythological, or textual; the doctrinal, or philosophical; the ethical, or legal; the social, or institutional; the ritual; the experiential; and the artistic. ${ }^{3}$ In most survey courses the explanation of texts and beliefs takes up so much time there is little left for the artistic dimension to be adequately presented. Having spent much of my life at the ballet bar and keyboard, I always regret this imbalance.

While developing a new freshman honors course the following confronted me: what if the presentation is backwards? I decided to reverse the order of topics and introduce students to other religions, beginning with sacred space and the arts. As I had hoped, the universal voice of the arts resonated with their young minds in ways foreign texts and complex concepts never had. Of course it would. Is this not how people have always first learned their own faith traditions - through beautiful pictures and sounds that brought to life the stories they heard? Why not approach "the other" the same way? After all, humans are visual and auditory beings, who respond to emotions with movement. I found that letting the arts first speak for the religions made what originally seemed so "other," more accessible. These "other people" were now recognized as lovers of music, performers of dance and drama, and creators of inspiring art. The wide variety in subject matter, media, and style naturally led to engaging discussions and, ultimately, better understandings of the values, ideals, and beliefs within other traditions.

One may ask, with so many art forms and religions, not to mention the wide variety of cultural expressions of each, where do you begin? Rather than distinguishing between "high" art and "popular" art, I believe any form that is employed as emotive or didactic may be considered religiously significant. As

2. John R. Hinnells, "Religion and the Arts," in The Routledge Companion to the Study of Religion, ed. John Hinnells (London: Routledge, 2005).

3. Ninian Smart, The Religious Experience (Upper Saddle River, NJ: Prentice Hall, 1996). 
for religions, one way to narrow the field is to divide them into three categories: Eastern, Indigenous, and Western. Of course, there is wide diversity within each major category, with much "cross-fertilization" among them, and generalizations are not the best way to approach anything. However, there is enough commonality of expression within each group that even the uninitiated may discern most "Buddhist art" from "Islamic art," so our introductory method is not without merit.

Adherents within each of these three major categories of belief look to guides and guideposts for their spiritual journeys. Artists serve the vital role of providing signs along the way, and sometimes, even setting a new course altogether. Artists instruct, reinforce beliefs, remind of commitments, and uplift spirits. With countless comparative themes and motifs, where can we best slip in to observe others' journeys and access their sacred, artistic portals? I suggest starting with the art and music most often encountered (or most easily accessible), paying close attention to symbolism, which forms the vocabulary for each tradition. Classical examples prepare us to more fully comprehend contemporary expressions that, even if radically new in approach, retain depth of spiritual meaning.

For Eastern art I offer a few examples from the classical expressions of Hinduism and Buddhism. These religions provide images, music, and dance to guide adherents on their journey within themselves to find the reality of the oneness of the universe. Indigenous peoples span the globe, comprising approximately four percent of the world's population. I have selected art forms from native peoples of North America, communities who also see art, music, and dance as sacred aspects of their lives together. Finally, Western traditions also recognize life as a journey, with each group offering "a way" to follow. For Jews, Muslims, and Christians the path is to God who is transcendent - yet engaged with the world he created. Within these traditions artists serve as way-showers, or guides, toward the divine being.

Although not the subject of this essay, I have found sacred locations valuable in the introduction of other faiths. Temples, mosques, synagogues, churches, as well as nontraditional spaces such as stone circles and dramatic waterfalls, become galleries and stages for the artistic expression of each tradition. When seen as places filled with sights and sounds recognizable as art, they become less foreign and intimidating.

\section{Eastern Sacred Portals: Hinduism}

We begin in India with Hindu thought, arguably the oldest living belief system. Cast in jewelry, worn on T-shirts, and seen everywhere in art and print, the Hindu religious symbol aum (the aumkara) is the consummate mystical representation of the cosmos itself. India supports a rich visual culture, but we begin with music, for the ancient aum is considered the 
primordial sound, the sacred vibration through which the incomprehensible Ultimate Reality manifested the universe. All other sounds are said to be contained within this sacred incantation. The three letters "AUM" represent the supreme Brahman, the ultimate consciousness, understood through three aspects: Brahma (creation), Vishnu (Preservation), and Shiva (destruction). Hinduism teaches that all reality is united in this beginningless, endless, sacred sound that transcends all barriers. Humans, mired in the work-a-day world, find it hard to comprehend this unity, missing their own participation in the oneness. True self-realization is aided by intoning the aum at the beginning of prayer or meditation.

Just as sound reverberates through all things, so too, all of existence is interconnected; therefore, music illustrates the unity and divinity of all things. Indian sacred music leads the devotee along the journey inward toward selfrealization. This musical form Raga Sangeet dates back to the ancient Vedic hymns of almost 2000 years ago. For a contemporary introduction, I suggest the music of Ravi Shankar, hailed the "Godfather of World Music" by Beatle George Harrison. Since sound is divine (Brahman), music is a legitimate spiritual discipline. Raga offers an experiential perception of the unity and essence of the universe. Indian performing artists evoke moods such as romance, humor, anger, fear, or disgust. This highly complex, yet improvised form cannot be "learned." What the master inspires, is given life, or a "soul" by the student. There is a saying in Sanskrit: "That which colours the mind is raga."4

Other portals to Ultimate Oneness include divinities that populate Indian mythology, offering timeless stories of love, loyalty, and devotion. Sculpted images of precise proportions may be seen as either objects to help devotees focus their thoughts or as sculptures in which the divine actually resides. ${ }^{5}$ Devotion to a particular divinity leads to good karma and eventual release from reincarnation. Krishna, one of the ten avatars of the god Vishnu, is the most popular choice for devotion and artistic representation. Classical imagery offers an immediately recognizable form, for this "dark" avatar of sacred literature is often depicted as blue - the "cosmic" color - to represent the god's universality. Although long considered inappropriate, the mass production of icons became popular with the art of Narottam Narayan (1896-1992). In his most famous 1934 painting of Krishna, Murli Manohar, Narayan incorporated a photographic facial image, giving the avatar an unforgettable ethereal aura. ${ }^{6}$ Other contemporary Indian artists continue to popularize traditional imagery. Forbes magazine named

4. "What is the Motif of a Raga?," Quora, accessed February 07, 2016, https://goo. gl/dfO6UQ.

5. Diana L. Eck, Darsan: Seeing the Divine Image in India (New York: Columbia University Press, 1998).

6. "Narottam Narayan," Wikipedia, the Free Encyclopedia, accessed February 07, 2016, https://goo.gl/1PFCW8. 
Maqbool Fida Husain the "Picasso of India." His Ganesha and Dancing Woman are representative of the work produced by members of the Progressive Artists Group to which he belongs. ${ }^{7}$

Hindu music and art merge, bringing classical images to life through dance, recalling ancient stories in skillful, expressive movement. Diverse regional folk expressions celebrate life itself. Originally choreographed for temple ritual, traditional dance forms share exact, expressive mudras, or hand gestures, that are, for the performer, worship and meditation. Drama and dance combine in the storytelling as the dancers temporarily embody the divine guides - joining music, dance, and drama in the ultimate religious experience.

\section{Buddhism}

The most recognizable symbol of Buddhism is the image of the founder, Siddartha Gautama; however, early Buddhists eschewed iconography, choosing instead aniconic symbols like the wheel, mandalas, or footprints. Detailed wheels of life represent the endless cycle of birth and death due to karma accrued during each successive life, and also the impermanent nature of the material world. Colorful, abstract mandalas guide the viewer inward, leading to cosmic and self-realization. Once, while watching a Tibetan monk creating a huge, colorful sand mandala, one grain of sand at the time, I was shocked to see him destroy the finished product! Grieving the loss, I had missed the point: the creative process was the artist's own spiritual journey. This meditational practice quiets the mind, canceling out distractions to focus thought inward. Meditation itself may be considered an art form, for it is practiced, not learned.

As time passed, artists began rendering the Buddha himself. Today a variety of images may be found just about anywhere: from fine art galleries to trendy home furnishings stores. Many examples, spanning centuries and crossing cultures, are on display at the Metropolitan Museum of Art in New York, and may be seen online. No matter the medium, all representations of the Buddha reveal deep, spiritual elements. For example, the unusually long earlobes, as if stretched by heavy earrings, represent the life of luxury renounced in order to seek the source of and remedy for life's universal suffering. Hand gestures convey a range of messages from bestowing blessings to warding off evil. The overall posture is also significant. A thin, austere Buddha illustrates the sage in his earliest, ascetic phase. The peaceful, sitting posture of the Buddha in meditation silently exhorts the viewer to follow his example. Sometimes the Buddha is depicted holding a wheel representing his teachings, or the dharma he preached following his

7. Susan Adams, "The Picasso of India," Forbes, accessed February 07, 2016, http:// goo.gl/2krrlo. 
enlightenment. The eight spokes on the wheel stand for the eightfold path, the "how-to-manual" of the Middle Way, or path of enlightened, compassionate living, which leads to self-awareness and escape from the suffering of reincarnation: nirvana, bliss.

Contemporary artists continue to incorporate traditional concepts in their innovative representations of Buddhism. Sculptor Sukhi Barber utilizes empty space to represent sunyata, or the Buddhist doctrine of emptiness. Other new and noteworthy art includes works by Jewoo Jeon, Sooyung Lee, and Suzanne Rees Glanister. ${ }^{8}$

\section{Indigenous Sacred Portals: Native American Spirituality}

When browsing through gift shops throughout the United States, one finds many items representative of Native North American culture. One highly symbolic object consists of a hoop, either plain or highly decorated, with a spiderweb design woven inside. When hung near a bed, this "dream-catcher" will "catch" the wisdom made available during the night when sleep is deep and dreams are vivid. "Negative dreams," trapped until morning, dissolve in daylight. The more nimble positive dreams slip down the attached feathers to the dreamer below. The essential, basic element of these "dream filters" is the hoop, its circular form representing the power of communal unity.

Dreams are important to Native Americans who look back to their beginnings in a "dreamtime" before the first people "emerged" from the ground into the world as we know it. Just as these first tribal members emerged as a group, so their focus remains on life together. Great Spirit set the course of the ancestral "Red Way"; now they are to walk it as community. Respect is fundamental: respect for nature, other people, and the spirit realm. The circle, artistically employed in every medium, represents this strong emphasis on the community here and now. The native drum brings the circle to life, drawing the community into dance - a sacred reenactment and powerful, unifying force. Movements intentionally engage the entire person and are performed low to the ground. While dance is still a vital component of community life, historically, dances such as the Ghost Dance of 1890, provided a way to corporately resist assimilation and restore peace and prosperity.

Native peoples also have guides for their journey. Animals who conversed with the first humans during dreamtime continue to be sought as guides for the Red Way. Wisdom, first acquired individually during rituals like the Sundance, or Vision Quest, becomes part of the collected, authoritative experience for the community. Animal guides dominate native art, including northwestern totem poles. Contemporary artists continue this motif with images highlighting animals

8. "Wisdom and Compassion Art Exhibition at Mokspace, London." Buddhist News, accessed February 07, 2016, http://goo.gl/oJ6Z6T. 
known for guidance in particular aspects of life. Work by artists, like Choctaw Dyanne Strongbow, elicits the respect due these brothers and sisters from the dreaming. R. C. Gorman, Navajo painter, print maker, and sculptor is famous for representations of "earth mother." Kiowa painter, Stephen Mopope, (1900-1974) documented on canvas the feather dance, a version of the politically charged Ghost Dance, that was still practiced during his life (1900 - 1974). Famous for his depiction of contemporary dancers, Mopope captured in murals the detailed costumes and movement of Plains dancers, one of which may be seen in the Department of the Interior Building in Washington, DC. ${ }^{9}$

\section{Western Sacred Portals: Judaism}

The most ancient symbol of Judaism, the menorah, or seven branched candle stick, takes us all the way back to the days of the early Israelites wandering in the desert. Originally part of the accoutrements of the portable sanctuary, this candelabrum stood centuries later in the Temple in Jerusalem where the one God was believed to reside. Now the Hanukkah (dedication) menorah memorializes the $2^{\text {nd }}$ century BCE political victory when one day's allotment of oil miraculously kept the temple light shining for eight days. For Jewish people, the menorah represents the spiritual light of Judaism that can never be extinguished and their determination to live life in community. God, who is holy and "other" than his creation, reveals himself through word and deed. Therefore, the most sacred object in a synagogue is the torah scroll, containing God's words through prophets and accounts of his participation in history.

We find two paths within Judaism, and Jewish art has represented both trajectories. First, the joyful celebration of life given by a good creator is best captured by Hassidic Jew and pioneer of modernism, Marc Chagall (1887-1985). His most recognizable works wed strong, bright colors in the cubist style to depict an exuberant world of folk images, often merging fantasy and religion employing animals, musicians, laborers, and Jewish folklore. A master of multiple media, Chagall included in his work stained glass windows for cathedrals and the United Nations. Later in his career he produced images of Jewish martyrs and refugees, and dramatic scenes from the Bible, including over 100 etchings of biblical themes. ${ }^{10}$

The other journey within Judaism is the way of "exile and return" - of scattering and reuniting, of distance from the Creator and the way back into the

9. "Native American Art: Sandpainting, Baskets, Pottery and Painting," Native American Art: Sandpainting, Baskets, Pottery and Painting, accessed February 07, 2016, http://goo.gl/nrY0b.

10. The Pedagogic Center, The Department for Jewish Zionist Education, The Jewish Agency for Israel, "Marc Chaggall," Jewish Virtual Library, accessed February 07, 2016, http://goo.gl/M34NZm. 
divine presence. The most universally recognized and evocative symbol of Judaism, the Magen David, or Star of David, is said to have been either the shape of King David's shield, or an emblem on it. However, this geometric star motif is actually a fairly recent addition to Jewish imagery, dating back to kabbalistic associations of the $14^{\text {th }}$ century. Most memorably, the Nazis forced Jews to wear the distinctive star on their clothing in order to isolate them socially and geographically, associating it forever with humiliation and tragedy. The sixpointed star has now been recast as a powerful symbol of community solidarity, emblematic of a people who will forever see life through the lens of the Holocaust. Contemporary artists reify the horror in their portrayals of the angst, the confusion, the wrestling with God. Jan Komski, Polish Auschwitz survivor and painter, memorializes eyewitness testimony through graphic depictions of the depth of suffering in Auschwitz. ${ }^{11}$

\section{Islam}

For an artistic introduction to Islam, I suggest calligraphy of the divine name - Allah - as an authentic emblem for a faith focused not on images of natural forms, but on representations of divine speech. Islamic tradition supports a proscription against artistic representation of life forms in order to avoid inordinate reverence for a mere image of something only God can create. More importantly, the regulation keeps believers focused on the radical unity of God and the harmony of his creation. Muslim people are not left without artistic portals through which they may express their awe and faith. Intricate designs of mathematical harmony depicted through ordered repetition may be found in tile work gracing the walls of buildings, mosques, and on various decorative pieces.

The focus on "word" is remarkably fitting for a people whose first revelation from God was "Read!" For the Muslim, words have power, for seeing the words of God is a divine encounter. Originally predating the rise of Islam, Arabic calligraphy developed as a religious art form during the Umayyad caliphate, which ended in 749. The mosaic tile belt inscription in the Dome of the Rock in Jerusalem is representative of this period. Since that time, many other forms and styles have been created. Far from superficial embellishments, calligraphy replaces images and "the word" becomes an indispensable portal to the sacred, and the effort of the calligrapher becomes a meritorious devotional practice. The artist may also use words to compose vegetal arabesque or elegant geometrical forms. Calligrams, or anthropomorphic figures like birds and animals created from words are also popular.

American master of calligraphy Mohamed Zakariya converted to Islam as a teenager, and as a way to express his newfound faith, taught himself the Arabic

11. "Auschwitz Paintings by Survivor Jan Komski," Auschwitz Paintings by Survivor Jan Komski, accessed February 07, 2016, http://goo.g1/LSukJv. 
language and the art of calligraphy. Noteworthy, yet untrained, his early work caught the eye of Turkish master Hasan Celebi, with whom he continues to practice. ${ }^{12,13}$

The Sufi tradition has within its ranks disciplined mystics who seek divine love and knowledge through the sacred portals of music and dance. While spinning, these "whirling dervishes" repeatedly invoke the name of Allah - a form of dhikr, or remembrance of God. Each element of this formal ceremony has spiritual significance for both an inner and outer journey. From the conical hats worn, representing the adept's tombstone, to the black cloaks representing their graves, the dancer's attire represents death to the ego. The seemingly effortless spinning, as if on an axis, suggests that all things of the universe spin, or revolve, like the spinning of atoms, and the circulation of blood. ${ }^{14}$ We may observe and listen to the reed flutes, lutes, kettle drums, and cymbals. We may appreciate the effort, but cannot fully enter into the profoundly intimate experience. Just as the creation of a sand mandala is the meditative journey of the artist monk, so the dance of the dervish is his own solitary journey. However, the ritual does provide a conduit for divine grace, for as the dervish reaches one arm upward to acquire divine energy, the other arm channels the received power down as an earthly blessing. Followers of the mystical poet Mevlana Jelaleddin Rumi (1207-1273), the Mawlawi order, preserve this dramatic "dance" and musical ceremony representing the human mystical journey to the "Perfect." Rumi penned: "There are many roads which lead to God. I have chosen the one of dance and music."15 In 2005 UNESCO named the Turkish "Mevlevi Sema Ceremony" one of the Masterpieces of the Oral and Intangible Heritage of Humanity. ${ }^{16}$

\section{Christianity}

In Christianity there is a "way" to be embraced: following in the footsteps of the founder, Jesus Christ. In this monotheistic faith, the shift from image to

12. Piney Kesting, "Saudi Aramco World: The World of Mohamed Zakariya," Saudi Aramco World: The World of Mohamed Zakariya, accessed February 07, 2016, https://goo.gl/4pTrRG.

13. "A Life in Artistry - MohamedZakariya.com," A Life in Artistry MohamedZakariya.com, accessed February 07, 2016, http://goo.gl/5K5pVl.

14. Chris Koentges, "13 Things the Whirling Dirvishes Can Teach You About Spinning Until You're Dizzy Enough to Puke," Very Ethnic 2012, accessed February 07, 2016, http://goo.gl/HeOSsD.

15. "Whirling Dervishes in the Islamic Tradition," Whirling Dervishes in the Islamic Tradition, accessed February 07, 2016, http://goo.gl/XzRRrc.

16. "Third Proclamation of Masterpieces of the Oral and Intangible Heritage of Humanity," Third Proclamation of Masterpieces of the Oral and Intangible Heritage of Humanity, accessed February 07, 2016, http://goo.gl/NyayFM. 
word takes on new meaning. "Word" is no longer the word inscribed; God taking on human form becomes the "Word made flesh." For the Christian, the Word, Jesus Christ, is the way; he is not just a guide or messenger. Stories of his life are of utmost importance for believers of all denominations. The cross represents the defining event for Christianity: the death of Jesus Christ on behalf of humankind, and his triumphant resurrection.

Christians have wrestled with the appropriateness of the arts for millennia. Historically, the Christian story was taught to congregations through stain glass windows and sculptures on the facades of magnificent churches, for even if literate, common people had no texts to read for themselves. Paintings depicting the incarnation, life, death, and resurrection of Jesus Christ are numerous and almost universally understandable. Images of the baby Jesus in a manger represent the Christian belief in the incarnation of the third person of the one, triune God: the eternal "Word of God." In the Adoration of the Shepherd, by George de la Tour, 1644, light emanates from the infant, expressing in paint that Jesus came to be a light drawing people back to God. Contemporary artist Andrew Gadd chose to emphasize the vulnerability of the baby Jesus in his work Bus Shelter Nativity. Images of Jesus on a cross illustrate the death of Jesus as the price he paid to atone for humanity's life lived apart from God. Powerful representations include Christ of St. John of the Cross by Salvador Dali and Crucifixion by Pablo Picasso, 1930. Rembrandt van Rijn created a masterpiece on the biblical theme of Jesus' victory over death, The Resurrection, in 1635. Other contemporary works include The Risen Christ (1957) by Michel Ciry, Easter Morning by modern artist He Qi and the bronze statue Christ Rising (1998) by Frederick Hart. This is the "good news" of which Christians speak: that those who trust in Christ's sacrifice will live with God forever. Jesus now rules from heaven, a concept rendered in the mosaic Christ Pantocrator (1260) in Hagia Sophia. Yet, not all Christian doctrine is as easily depicted. The mysterious triune nature of God has been more challenging; artists of all generations and styles have typically resorted to similar symbols. Jesus is often seen with a dove, representing the Holy Spirit, and a pair of hands, representing God the Father, as in The Baptism of Christ (1472-75) by Verrocchio.

Christian sacred spaces host artistic portals of many kinds, including sacred music from Beethoven, Mozart, and Stravinsky to Michael W. Smith and Steve Green. Johann Sebastian Bach (b. 1685), considered by many church musicians as the greatest composer for Christian worship, wrote "The aim and final end of all music should be none other than the glory of God and the refreshment of the soul."17 Christian music ranges in style from cantatas and arias to contemporary hip-hop. Southern Gospel artists like Andraé Crouch

17. "Johann Sebastian Bach Quote," BrainyQuote, accessed February 07, 2016, http://goo.gl/vJn5Gc. 
and choirs like The Brooklyn Tabernacle Choir give a contemporary twist to an old expression of praise.

\section{Conclusion}

There have always been suppressors of the arts. Even Plato recognized the influential, even manipulative power of the arts and counseled caution. Throughout history conquerors have sought to eliminate the arts of vanquished cultures. Political regimes would eliminate the arts in order to elevate the human order. Zealots would suffocate the arts in the name of religion. It is the sheer emotive power of art that has been feared. Thankfully, these efforts fail due to the indomitable creative impulse of human beings.

Deriving a religious understanding via the arts does not make it less true -only more accessible. Artists invite us to join them as they express beliefs through the universal language of music, art, and dance. Eastern traditions offer a journey inward toward self-awareness and enlightenment - a journey initiated by sound, and guided by images brought to life and experienced through dance. Indigenous groups focus on the journey taken, not inwardly and individually, but communally, as illustrated through drums and dance, often led by animal guides. Western traditions also see life as a journey, but as a way to a divine reality beyond this world. The God who creates and reveals calls humankind to a journey to himself, guided by his word. This shift to "word" does not preclude art, for God is the ultimate artist: his canvas and stage the entire world. These monotheistic faiths may describe God differently, but they share similar traditional sacred portals. Nor does Western thought neglect the inner journey, for humans still crave an internal peace that is best delivered through artistic expression. Nothing calms the spirit like music, or rouses the soul like song. Music still reaches to heaven and sacred dance provides the mystic a portal into the divine presence.

Since we now live in a world where people take selfies at Auschwitz, we must take the time to instill the value of, and the respect due, all that is considered sacred, especially that which is revered by "the other." To do so will help us preserve all of the world's treasured sacred portals. I am confident the next generation of visual and performing artists will find new creative compositions to bring the shrinking world together in dialogue in ways never imagined before. 


\section{References}

"A Life in Artistry - MohamedZakariya.com." A Life in Artistry MohamedZakariya.com. Accessed February 07, 2016. http://goo.gl/5K5pVl.

Adams, Susan. "The Picasso of India." Forbes. Accessed February 07, 2016. http://goo.gl/2krrIo.

"Auschwitz Paintings by Survivor Jan Komski." Auschwitz Paintings by Survivor Jan Komski. Accessed February 07, 2016. http://goo.gl/LSukJv.

Eck, Diana L. Darsan: Seeing the Divine Image in India. New York: Columbia University Press, 1998.

Eliade, Mircea, and Willard R. Trask. The Sacred and the Profane: The Nature of Religion. New York: Harcourt, Brace \& World, 1959.

Hinnells, John R. "Religion and the Arts." In The Routledge Companion to the Study of Religion, edited by John Hinnells. London: Routledge, 2005.

"Johann Sebastian Bach Quote." BrainyQuote. Accessed February 07, 2016. http://goo.gl/vJn5Gc.

Kesting, Piney. "Saudi Aramco World: The World of Mohamed Zakariya." Saudi Aramco World: The World of Mohamed Zakariya. Accessed February 07, 2016. https://goo.gl/4pTrRG.

Koentges, Chris. "13 Things the Whirling Dirvishes Can Teach You About Spinning Until You're Dizzy Enough to Puke." Very Ethnic 2012. Accessed February 07, 2016. http://goo.gl/HeOSsD.

"Narottam Narayan." Wikipedia, the Free Encyclopedia. Accessed February 07, 2016. https://goo.gl/1PFCW8.

Native American Art: Sandpainting, Baskets, Pottery and Painting. Native American Art: Sandpainting, Baskets, Pottery and Painting. Accessed February 07, 2016. http://goo.gl/nrY0b.

Smart, Ninian. The Religious Experience. Upper Saddle River, NJ: Prentice Hall, 1996.

The Pedagogic Center, The Department for Jewish Zionist Education, The Jewish Agency for Israel. "Marc Chaggall." Jewish Virtual Library. Accessed February 07, 2016. http://goo.gl/M34NZm.

"Third Proclamation of Masterpieces of the Oral and Intangible Heritage of Humanity." Third Proclamation of Masterpieces of the Oral and Intangible Heritage of Humanity. Accessed February 07, 2016. http://goo.gl/NyayFM.

"What is the Motif of a Raga?" Quora. Accessed February 07, 2016. https://goo.gl/dfO6UQ.

"Whirling Dervishes in the Islamic Tradition." Whirling Dervishes in the Islamic Tradition. Accessed February 07, 2016. http://goo.gl/XzRRrc.

"Wisdom and Compassion Art Exhibition at Mokspace, London." Buddhist News. Accessed February 07, 2016. 